\title{
Tropical Residual Soil Properties on Slopes
}

\author{
${ }^{1}$ M.F.Ishak, ${ }^{2}$ M.F. Zolkepli and ${ }^{3}$ M.Affendy \\ 1,2,3 Faculty of Engineering Technology, University Malaysia Pahang, 26300, Kuantan, Pahang, Malaysia

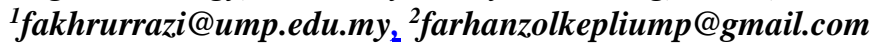

\begin{abstract}
Tropical residual soil is a product of chemical weathering, thus its characteristics are dependent upon environmental factors such as parent rocks, climate, topography and age. This type of soil can be found in many countries all over the world, especially in the tropical region. Since there are many accident happens due to slope failure, a comprehensive laboratory study need to be conducted in order to determine the properties of soil located at Pahang Matriculation College. Several experiments involving physical index and engineering properties of soil are conducted. The typical tropical residual properties are showed and can be considered as sandy SILT of high plasticity.
\end{abstract}

Index Terms- Residual soil, index properties, engineering properties, unsaturated soil

\section{INTRODUCTION}

Tropical residual soil can be defined as a soil weathered in-situ where the original rock structure is totally destroyed by weathering and has not been transported from its original location (Brand and Philipson, 1985; Blight, 2012; Public Work Institute Malaysia, 1996; Jia et al., 2014; Rahardjo et al., 2004). The definition of tropical residual soils varies from region to region and country to country. According to (Futai et al., 2004; Fourie et al., 2012), behaviour of residual soils do have structured soils bonding effect and can arise due to different conditions.

Townsend, 1985 and Salih, 2012 stated that residual soil is the result of chemical weathering and several factors like climatic factors, raw materials, topography, flow and age are the characteristics of engineering residual soil. These factors will include the engineering characteristic of residual soil. According to Ahmad et al. (2006), the in-situ behaviour of soil is complex as it depends on many factors. Peninsular Malaysia was covered by more than three-quarters of residual soils (Taha et al., 2000; Rahardjo et al., 1995).

According to Sokhanvar and Kassim (2013), many steep slopes in these residual soils often have a deep ground water table. Residual soil covers most of the land in Singapore and found commonly unsaturated condition due to deep ground water table (Zhai et al., 2016; Agus et al., 2005). Conceptually, residual soils are form at in-situ weathering and decomposition rock and remain at their original location. Physical and chemical processes of weathering leading to the formation of residual soils. Bland and Rolls (1998) stated that, in humid tropical regions, physical and chemical breakdown can be categorized into decomposition that altering of soils.

As proposed by International Association of Engineering Geology, IAEG (1981) and International Society for Rock Mechanics, ISRM (1981), residual soil is formed from weathering process leading to the formation that is highly complex cannot be used as a general guide to be relative of properties residual soils to its parent rocks. Normally, residual soils formed from parent rocks of igneous and metamorphic but residual soils formed from sedimentary rocks also widespread.

The aim of this study is to determine the physical and engineering properties of residual soil located within the area of Pahang Matriculation College. This paper also highlighted several testing procedures that are required to determine physical index properties (disturbed samples) and engineering properties (undisturbed samples) of soils.

\section{METHODOLOGY}

The study was carried out at Pahang Matriculation College, Gambang, Pahang, Malaysia. Figure 1 show the study area. 


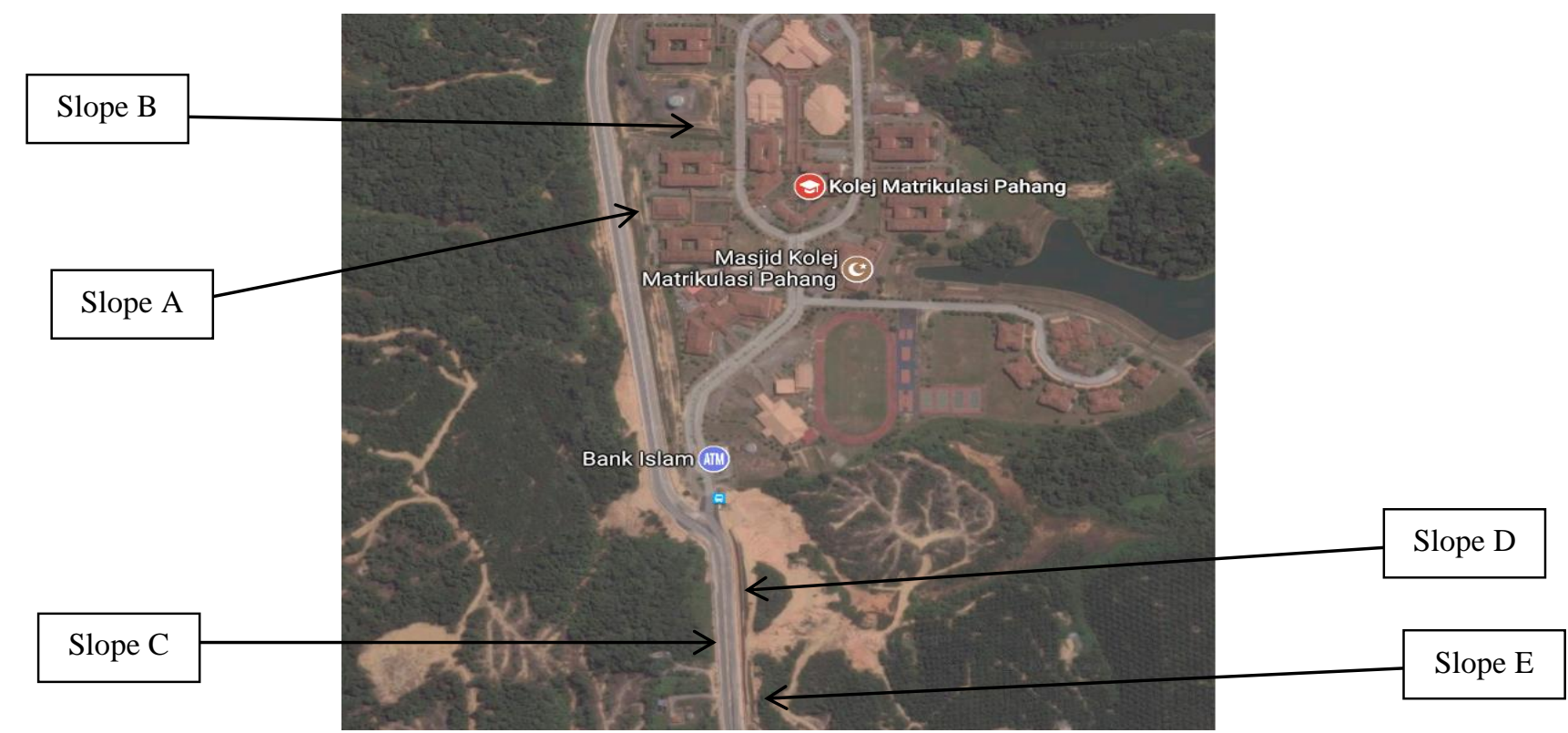

Figure 1: Study Areas at Pahang Matriculation College

The soil profile of the study area was characterized in order to identify the thickness and various distributions of residual soils. Generally, the site investigation consisted of trial pit to the collection of disturbed samples and undisturbed samples. Two locations of trial pit were excavated, both at the toe of the slope. Both samples (disturbed and undisturbed) were collected during the excavation works as shown in Figure 2. The field investigation works (trial pit) are carried out accordance to the British Standard Code of Practice BS 5930: 1999 and BS 1377: 1990 was used to conduct the laboratory tests.

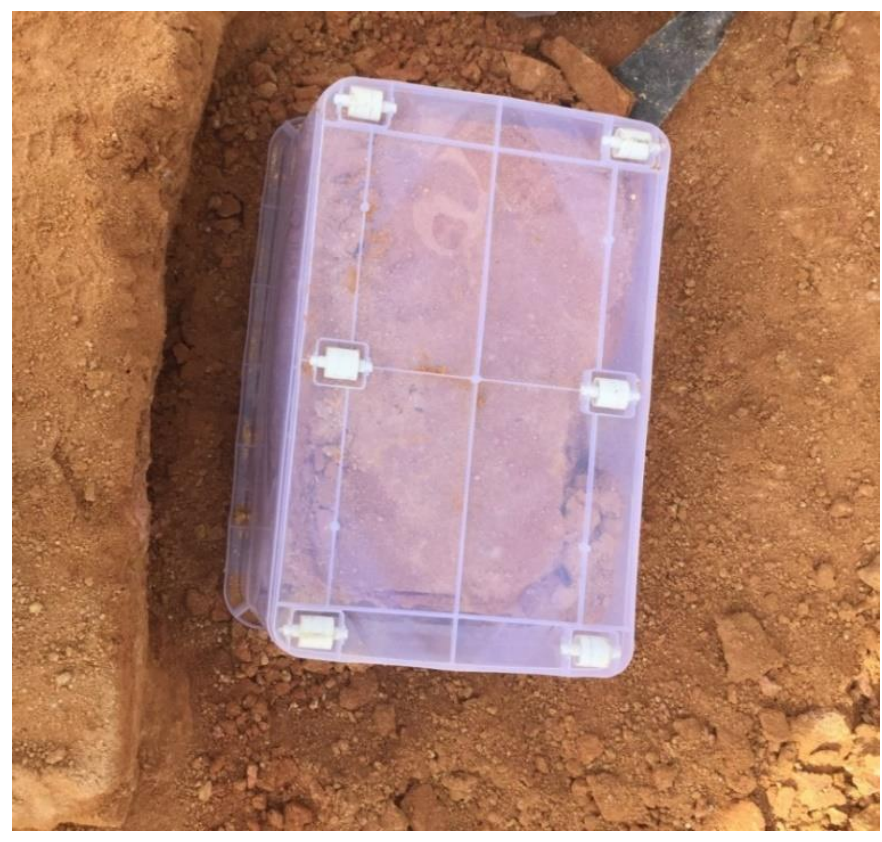

Figure 2: Soil Samples

The main purposes of the data collections are to determine the characteristics of soil material by conducting the laboratory experiments. In addition of the soil properties, the saturated parameters (soil cohesion and friction angle) were determined through laboratory works while unsaturated friction angle was assumed. The laboratory testing were conducted by dividing the tests according the group of soils, 
i.e., (1) disturbed soil samples (for index properties) and (2) undisturbed soil samples (for engineering properties). These samples were collected from field investigations at the ground surface (1 m depth) of the study area.

A series of laboratory testing to determine the soil properties, which can determine the index properties tests and also engineering properties tests were conducted. The main physical index properties tests conducted on the soils at this study area were particle size distribution, Atterberg Limit, specific gravity, and moisture content. To determine the engineering properties, Consolidation Isotropic Undrained (CIU) was applied for the soil of the study area. All experimental works were carried out according to the BS 1377: 1990.

\subsection{Index Properties Tests}

Physical index properties test was conducted in order to determine the engineering characteristics of the soil. Overall, index properties tests were carried out based on recommended procedures stated in BS 1377: 1990 which determine the particle size distribution, Atterberg limits, specific gravity and moisture content.

According to Ishak et al. (2013), the determination of particle size distribution from $20 \mathrm{~mm}$ down to clay fraction $(0.002 \mathrm{~mm})$ will involving sieve analysis test with the addition of hydrometer test was conducted. Figure 3 show mechanical sieve analysis. In this procedure, $0.5 \mathrm{~kg}$ bags of natural disturbed soil were broken down that passed $20 \mathrm{~mm}$ sieve. $100 \mathrm{~g}$ of soil sample was placed in the container together with $100 \mathrm{ml}$ of dispersant solution with the addition of $35 \mathrm{~g}$ sodium polyphosphate and $7 \mathrm{~g}$ sodium carbonate in $1 \mathrm{~L}$ of distilled water added into it. Later, the treated soil was washed through a 2 $\mathrm{mm}$ nested in a $63 \mu \mathrm{m}$ sieve and the retained soil particles were dried for dry sieving. For sedimentation test using hydrometer, the fine fraction was collected from the wet sieving. Figure 4 show the hydrometer test. To obtain full reading particle distribution curves, the results obtained from the two sets of procedure of dry sieving and hydrometer test were combined.

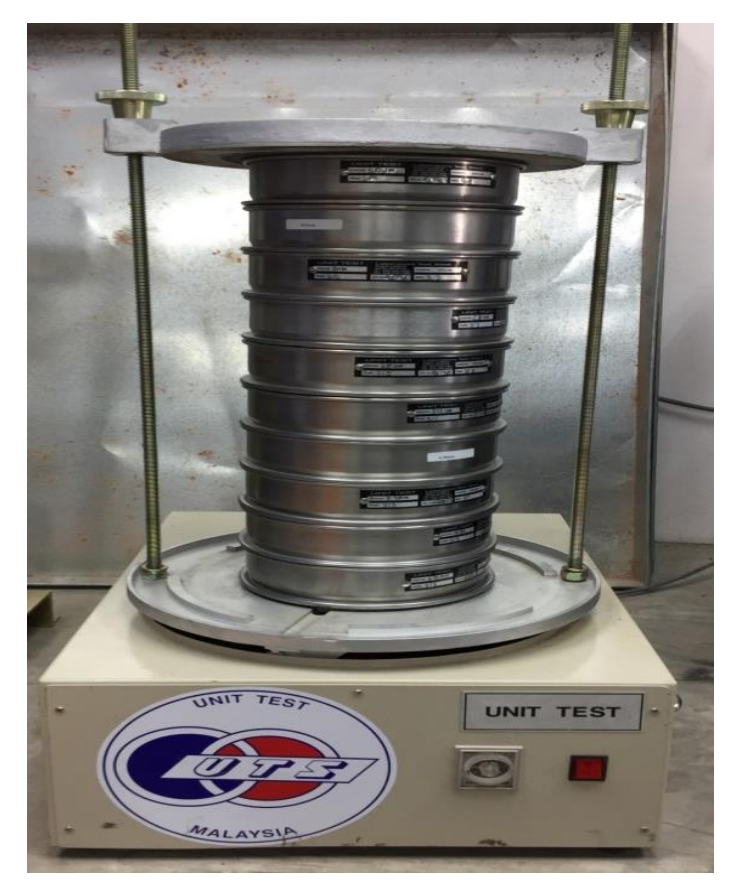

Figure 3: Mechanical Sieve Analysis 


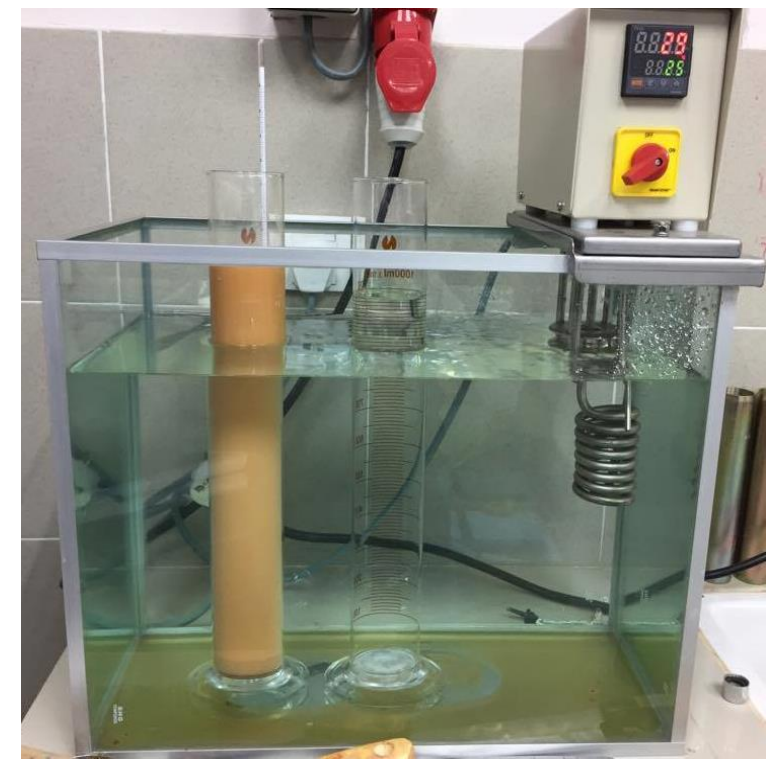

Figure 4: Hydrometer Test

The Atterberg limit test was defined as water that mixed with soil and determines water content which corresponds to condition of fine soil with different behavior Ishak (2014). To determine in term of plasticity that applied to fine soils such as silt and clay potion of $100 \mathrm{~g}$ fine soil indicated an ability to be rolled down to the diameter of $3 \mathrm{~mm}$ without breaking apart. The combination of Liquid Limit (LL), Plastic Limit (PL), and Plasticity Index (PI) were known as Atterberg Limit. Figure 5 show the Atterberg Limit test.

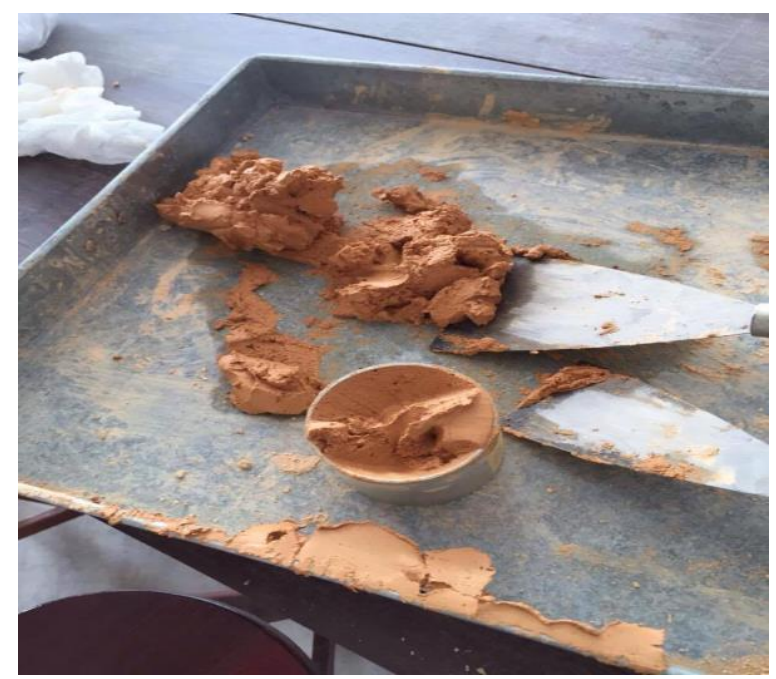

Figure 5: Atterberg Limit Test

To determine the specific gravity (also known as density of solid particles), a small portion of soil which about $5 \mathrm{~g}$ was placed in a small pyknometer with water Ishak (2014). Specific gravity was applied in determining porosity and void ratio of the soil. In-situ density (bulk density, $\rho_{b}$ and dry density $\rho_{d}$ ) of tropical residual soil were obtained by weighing and measuring the volume of undisturbed sample.

The simplest test but give a very important result is moisture content. The ratio of the mass of water removed from the wet soil against the dry soil is called moisture content. In this research, $50 \mathrm{~g}$ of soil 
was weighted and placed in the oven under the temperature of $105^{\circ}$ Celsius until the soil dried. The mass of the dry soil was calculated later to determine the moisture content in the form of percentage (\%).

\subsection{Engineering Properties Tests}

It is vital to specify the input density of the undisturbed soils in the laboratory experiments as soil density and void ratio governing the behaviour of the soil permeability. The determination of bulk and dry density $\left(\rho_{b} \& \rho_{d}\right)$ together with moisture content $(\omega)$ of the soil samples were conducted before conducting a series of Consolidation Isotropic Undrained (CIU) test. The test followed the procedures outlined in BS 1377: 1990 to obtain the relationship between moisture content with dry density.

Three soil samples ( $38 \mathrm{~mm}$ diameter with $76 \mathrm{~mm}$ height) must be prepared in order to conduct the CIU testing. Figure 6 show samples of undisturbed soil samples for CIU testing. These soil samples were prepared by using soil sample splitter.

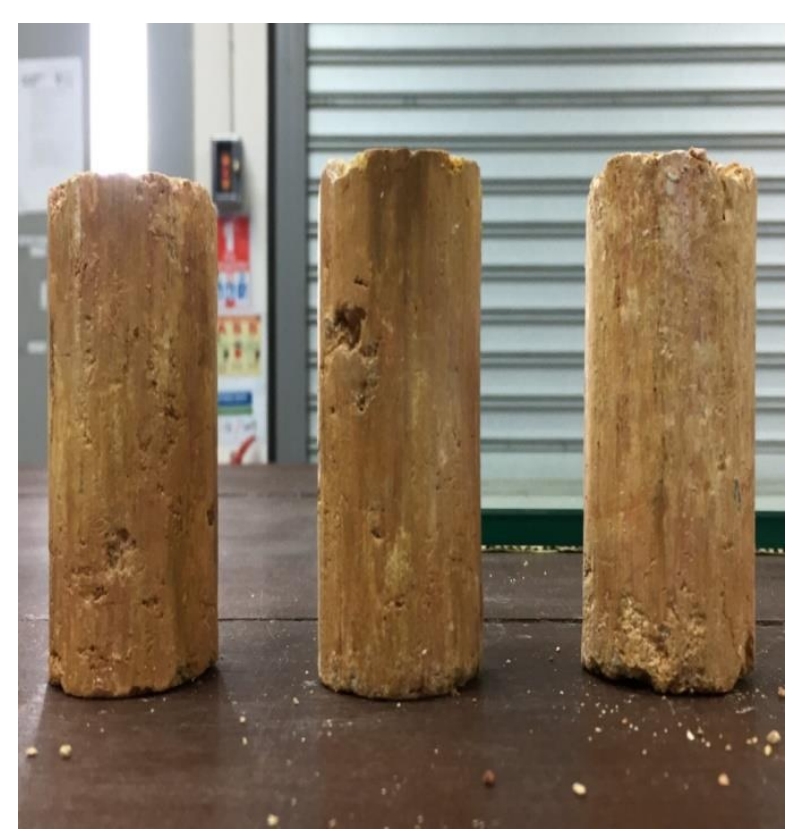

Figure 6: Undisturbed Soil Samples for CIU Testing

A series of CIU testing were conducted under different cell pressures $(100,150,200 \mathrm{kPa})$ to determine saturated $\left(c^{\prime}, \phi^{\prime}\right)$ shear strength parameters, while the unsaturated $\left(\phi^{b}\right)$ parameter will be assumed based on works from previous researchers. CIU testing were conducted using triaxial machine model GDS Lab. Figure 7 show the sample been prepared in triaxial machine. 


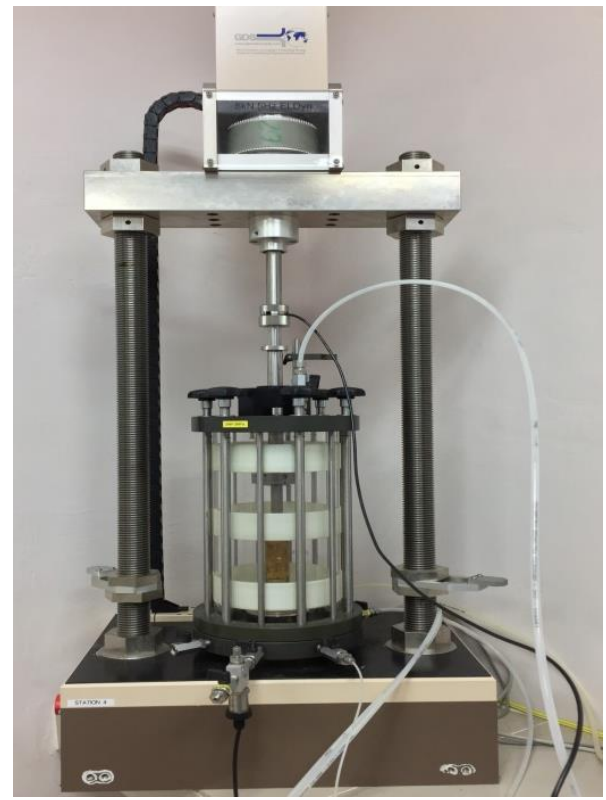

Figure 7: Consolidated Isotropic Undrained (CIU) Testing

\section{RESULTS AND DISCUSSIONS}

\subsection{Properties of Soil}

The summary of laboratory test result for soil properties of residual soil materials at Pahang Matriculation College is as shown in Table 1. The following section will discuss further about the soil properties.

Table 1: Properties of the Soil Materials in the Study Area

\begin{tabular}{c|c}
\hline Composition & Sandy SILT \\
\hline Natural Moisture Content (\%) & 17.95 \\
Gravel (\%) & 4.2 \\
Sand (\%) & 27.9 \\
Silt (\%) & 45.1 \\
Clay (\%) & 22.8 \\
Liquid Limit, LL (\%) & 70.0 \\
Plastic Limit, PL (\%) & 31.0 \\
Plasticity Index, PI (\%) & 39.0 \\
Soil Classification BSCS & MVS \\
Specific Gravity $\left(G_{s}\right)$ & 2.74 \\
Void Ratio $(e)$ & 0.69 \\
Porosity $(n)$ & 0.41 \\
Bulk Density, $\rho_{b}\left(\mathrm{~kg} / \mathrm{mm}^{3}\right)$ & 1.99 \\
Dry Density, $\rho_{d}\left(\mathrm{~kg} / \mathrm{mm}^{3}\right)$ & 1.67 \\
\hline
\end{tabular}




\subsubsection{Index Properties of Soil and Soil Classifications}

A series of laboratory testing for index properties has been conducted on residual soils at Pahang Matriculation College. Soil classification is the main physical index properties, which depends on several factors such as, Atterberg limits, moisture content, specific gravity, and particle size distribution.

Figure 8 show the particle size distribution at Pahang Matriculation College. Based on British Soil Classification System (BSCS), the tropical residual soil was classified as sandy SILT of high plasticity (MVS). The result of particle size distribution for a potion $100 \mathrm{~g}$ of soil sample consisted of $4.2 \%$ larger than $2 \mathrm{~mm}$ (gravel), $27.9 \%$ between size of $2 \mathrm{~mm}$ to $0.063 \mathrm{~mm}$ (sand), $45.1 \%$ between $0.063 \mathrm{~mm}$ to $0.002 \mathrm{~mm}$ (silt), and $22.8 \%$ is smaller than $0.002 \mathrm{~mm}$ (clay). From several origin of residual soil formation at Pahang Matriculation College, the distinct particle size distributions were observed and the average was presented in Figure 8.

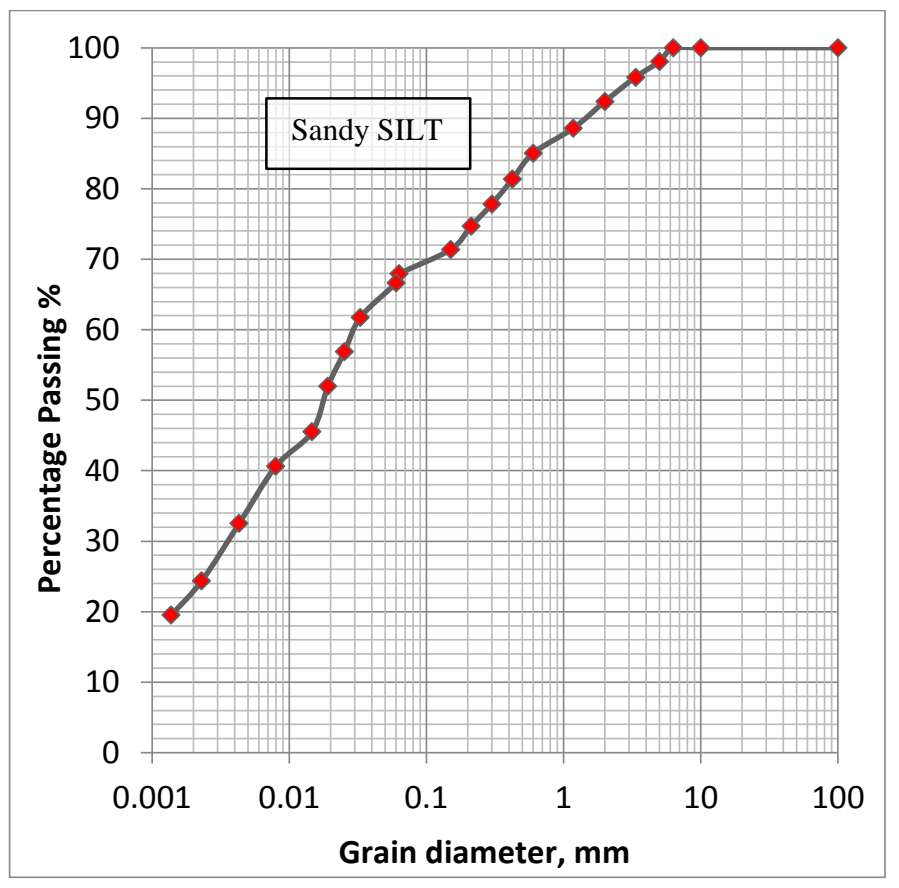

Figure 8: Particle Size Distribution of Tropical Residual Soil (sandy SILT)

Table 1, shown the Atterberg Limit of residual soils from Pahang Matriculation College indicated that the liquid limit (LL) of the soil was $70.0 \%$, plastic limit (PL) was $31.0 \%$ and Plastic Index, (PI) = LL$\mathrm{PL}=39.0 \%$. Based on the British Soil Classification System (BSCS), the soil at the field study can be classified as SILT of high plasticity (MHS). The average specific gravity is 2.74 of residual soils from Pahang Matriculation College.

\subsubsection{Engineering Properties}

According to (Fredlund et al. 1978; Fredlund et al. 1996; Ali, 2007), the new parameter introduced which is the unsaturated friction angle, $\phi^{b}$ is always less than or equal to saturated friction angle, $\phi^{\prime}$. According to Goh et al. (2010), assume the shear strength of soil is linearly proportional to matric suction, where $\phi^{b}$ is equal to $\phi^{\prime}$ when matric suction lower that air-entry value.

Table 2 show experimental shear strength values of soil at study area with value of $\phi^{b}$ angle. The effective saturated shear strength parameters ( $c^{\prime}$ and $\phi^{\prime}$ ) for the soil at Pahang Matriculation College were determined by performing the consolidated isotropic undrained (CIU) tests on three undisturbed 
soil samples. The unsaturated friction angle, $\phi^{b}$ was assumed lower than saturated friction angle, $\phi$ based on previous literature from other researchers.

Table 2: Experimental Values of Shear Strength with Values of $\phi^{b}$ of Residual Soil

\begin{tabular}{c|cccc}
\hline Researcher & Location & $c^{\prime},(\mathrm{kPa})$ & $\phi^{\prime},\left(^{\mathrm{o}}\right)$ & $\phi^{b},\left(^{\circ}\right)$ \\
\hline Author & $\begin{array}{c}\text { Pahang } \\
\text { Matriculation } \\
\text { College }\end{array}$ & 9 & 25 & 21 (assumed) \\
\hline
\end{tabular}

Based on the Mohr's Circle and the effective stress failure envelope for specimens 1,2, and 3 illustrated in Figure 9, the effective cohesion ( $\left.c^{\prime}\right)$, is $9 \mathrm{kPa}$ and the effective friction angle $\left(\phi^{\prime}\right)$ is $25^{\circ}$.

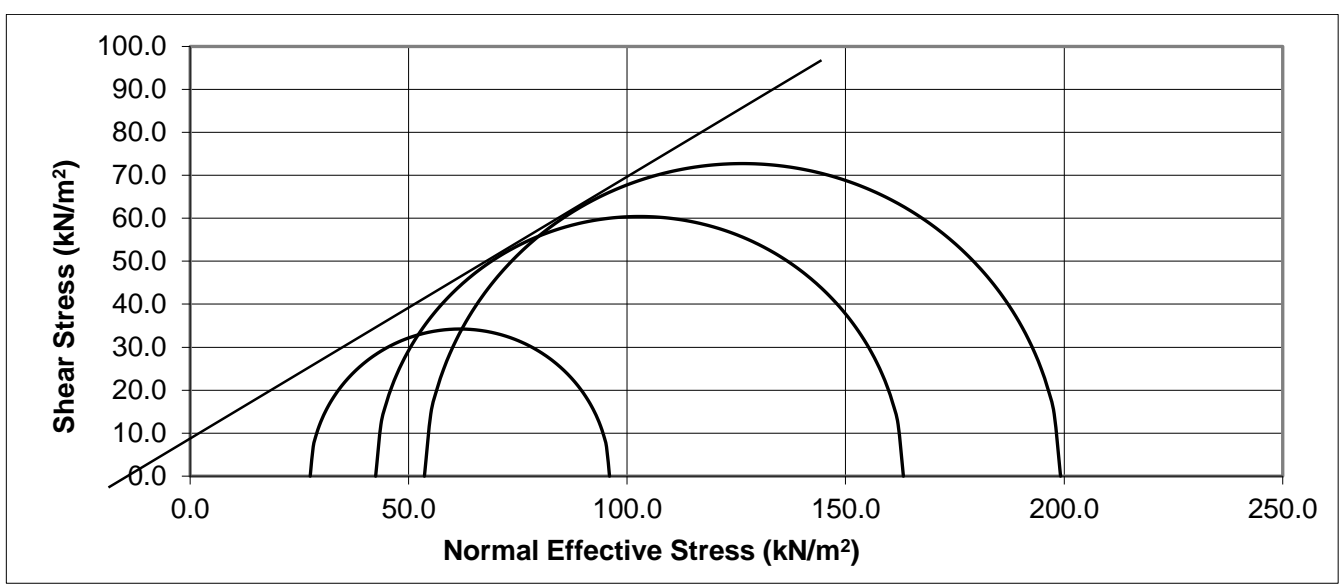

Figure 9: Effective Stress Failure Envelopes and Mohr's Circles for Sample 1,2 and 3

\section{CONCLUSION}

The experimental results from soil testing can be used to classify types of soil. Based on physical index properties results, the soil consisted of $4.2 \%$ gravel, $27.9 \%$ sand, $45.1 \%$ silt, and $22.8 \%$ clay with plasticity index of $39 \%$. The specific gravity of the soil is 2.74 with natural moisture content of 17.95 $\%$. The engineering properties of the soil gives $9 \mathrm{kPa}$ of cohesion $\left(c^{\prime}\right), 25^{\circ}$ of saturated friction angle $\left(\phi^{\prime}\right)$, and the assumed unsaturated friction angle $\left(\phi^{b}\right)$ is $21^{\circ}$. The type of tropical residual soil at Pahang Matriculation College can be considered as sandy SILT of high plasticity.

\section{REFERENCES}

[1] Brand, G.E. and Philipson, H.B. "Sampling and Testing of Residual Soils - A Review of International Practices", Technical Committee on Sampling and Testing of Residual Soils, International Society for Soil Mechanics and Foundation Engineering, 7-22. 1985.

[2] Blight, G.E. "Origin and Formation of Residual Soils", Mechanics of Residual Soils, London, UK, Taylor \& Francis Group plc. 2012.

[3] Public Work Institute Malaysia. "Tropical Weathered In-Situ Materials", Geoguides, 1-5. 1996. [4] Jia, J., Zhou, C., Jiang, N. and Lu, S. "Analysis of Stability of Residual Soil Slope and Treatment Measure", Electronic Journal of Geotechnical Engineering, 19, 3889-3898. 2014.

[5] Rahardjo, H., Aung, K.K, Leong, E.C. and Rezaur, R.B. "Characteristics of Residual Soils in Singapore as Formed by Weathering”, Engineering Geology, 73, 157-169. 2004. 
[6] Futai, M.M., Almeida, M.S.S. and Lacerda, W.A. "Yield Strength and Critical State Behaviour of a Tropical Saturated Soil", Geotechnique, 130(11), 1169-1179. 2004.

[7] Fourie, A.B., Irfan, T.Y., Queiroz de Carvalho, J.B., Simmons, J.V. and Wesley, L.D. "Microstructure, Mineralogy and Classification of Residual Soils", Taylor \& Francis Group plc, Londonm UK. 2012.

[8] Townsend, F.C. "Geotechnical Characteristics of Residual Soils", Journal of Geotechnical Engineering, 111, 77-92. 1985.

[9] Salih, A.G. "Review on Granitic Residual Soils Geotechnical Properties", Electronic Journal of Geotechnical Engineering, 2645-2658. 2012.

[10] Ahmad, F.A., Yahaya, A.S. and Farooqi, M.A. "Characterization and Geotechnical Properties of Penang Residual Soils wih Emphasis on Landslides", American Journal of Environmental Sciences, 2(4), 121-128. 2006.

[11] Taha, M.R., Hossain, M.K. and Mofiz, S.A. "Behaviour and Modelling of Granite Residual Soil in Direct Shear Test", Journal of Institution of Engineer Malaysia, 61(2), 27-40. 2000.

[12] Rahardjo, H., Lim, T.T., Chang, M.F. and Fredlund, D.G. "Shear Strength Characteristic of a Residual Soil", Canadian Geotecnical Journal, (32), 60-77. 1995.

[13] Sokhanvar, M. and Kassim, A. "Unsaturated Shear Strength Behavior under Unconsolidated Undrained Tests", Electronic Journal of Geotechnical Engineering, 18, 601-612. 2013.

[14] Zhai, Q., Rahardjo, H., and Satyanaga, A. "Variability in Unsaturated Hydraulic Properties of Residual Soil in Singapore", Engineering Geology, 209, 21-29. 2016.

[15] Agus, S.S., Leong, E.C., and Rahardjo, H. "Estimating Permeability Functions of Singapore Residual Soils", Engineering Geology, 78, 119-133. 2005.

[16] Bland, W. and Rolls, D. "Weathering", London: Arnold. 1998.

[17] IAEG. "Rock and Soil Description for Engineering Geological Mapping", International Association of Engineering Geology Bulletin, 24, 235-274. 1981.

[18] ISRM. "Basic Geotechnical Description for Rock Masses", International Journal of Rock Mechanics, Mining Science and Geomechanics, 18, 85-110. 1981.

[19] BSI. "Code of Practice for Site Investigations, (BS 5930)", London: British Standard Institution. 1999.

[20] BS. "Methods of Tests for Soils for Civil Engineering Purposes, (BS 1377: Part 1-9)", London: British Standard Institution. 1990.

[21] Ishak, M.F., Ali, N. and Kassim, A. "The Influence of Tree Induced Suction on Soil Suction Profiles", International Journal of research in Engineering and Technology, 2(9), 187-193. 2013

[22] Ishak, M.F. "Tree Water Uptake on Suction Distribution in Unsaturated Tropical Residual Soil Slope”, Doctor Philosophy, Universiti Teknologi Malaysia, Skudai. 2014.

[23] Fredlund, D.G., Morgenstern, N.R. and Widger, R.A. "The Shear Strength of Unsaturated Soil", Canadian Geotechnical Journal, 15, 313-321. 1978.

[24] Fredlund, D.G., Xing, A., Fredlund, M.D. and Barbour, S.L. "The Relationship of the Unsaturated Shear Strength to the Soil-Water Characteristic Curve", Canadian Geotechnical Journal, 33(3), 440448. 1996.

[25] Ali, N. "The Influence of Vegetation Induced Moisture Transfer on Unsaturated Soils", Doctor Philosophy, University of Cardiff, United Kingdom. 2007.

[26] Goh, S.G., Rahardjo, H. and Leong, E.C. "Shear strength Equations for Unsaturated Soil under Dying and Wetting", Journal of Geotechnical and Geoenviromental Engineering, April, 136(4), 594606. 2010. 